\title{
The Structure, the Effect of Variety Acids and Treatment Methods of Kidney Stones
}

\author{
Emine AYTAR $^{1 *}$ D, Hacer ÖNAL ${ }^{2}$ D, Şerife YALÇIN ${ }^{2}$ (D)
}

1* Harran University, Faculty of Arts and Sciences, Department of Chemistry, Sanlıurfa, Turkey

2 Harran University, Faculty of Arts and Sciences, Department of Physics, Sanliurfa, Turkey

Geliş / Received: 06/04/2021, Kabul / Accepted: 04/08/2021

\begin{abstract}
A kidney stone is one of the diseases that people have a lot of suffered and faced very often. Its treatment is generally performed conservatively, medically, or surgically according to the characteristics of the patient and the stone. In this study, the structure of calcium oxalate kidney stone from urinary system stone diseases is examined and the methods used in the treatment of this stone today, the success in the treatment, the advantages and disadvantages of these methods were compared and researched acid effect on the structure of these stone. The calcium oxalate structure was synthesized in this study. The effect of acetic acid, acetic acid glacial, citric acid, lemon and hydrochloric acid on this structure was investigated. Then, the structure of the stone was determined by XRD, FT-IR and SEM methods. The $\mathrm{CaC}_{2} \mathrm{O}_{4}$ stone was synthesized and examined using spectroscopic methods. The X-ray diffraction pattern of all syntheses has a similar structure and has a calcium oxalate peak. It is compatible with the literature. In the FT-IR spectrum, a broad spectrum peak was observed in the region between 3700 and $2760 \mathrm{~cm}^{-1}$ for all studied syntheses. It reveals the COM structure for $\mathrm{H}_{6}$, and the COD structure for $\mathrm{H}_{1}, \mathrm{H}_{2}, \mathrm{H}_{3}$, and $\mathrm{H}_{4}$. The effects of other acids on synthetic calcium oxalate were compared by using SEM images. It was obtained where the dimensional distribution of the particles was uniform and smaller than the others for the $\mathrm{H}_{4}$ which citric acid was added. It was observed that the tendency to cluster in the particles was higher than the others in the synthesis by adding glacial acetic acid.
\end{abstract}

Keywords: Kidney Stone, Calcium Oxalate, Acids, XRD, FTIR.

\section{Böbrek Taşlarının Yapısı, Çeşitli Asitlerin Etkisi ve Tedavi Yöntemleri}

$\ddot{\mathbf{O z}}$

Böbrek taşı, insanların çok çektiği ve çok sık karşılaştı̆̆ı hastalıklardan biridir. Tedavisi genellikle hastanın ve taşın özelliğine göre konservatif, medikal veya cerrahi olarak yapılır. Bu çalışmada üriner sistem taş hastalıklarından kalsiyum oksalat böbrek taşının yapısı incelenmiş ve günümüzde bu taşın tedavisinde kullanılan yöntemler, tedavideki başarısı, bu yöntemlerin avantaj ve dezavantajları karşılaştırılarak asit etkisi araştırılmıştır. İlk olarak kalsiyum oksalat yapısı sentezlenerek asetik asit, asetik asit glacial, sitrik asit, limon ve hidroklorik asidin bu yapıya etkisi araştırıldı. Ardından XRD, FT-IR ve SEM yöntemleriyle taşın yapısı belirlendi. $\mathrm{CaC}_{2} \mathrm{O}_{4}$ taşı sentezlendi ve spektroskopik yöntemlerle incelendi. Tüm sentezlerin X 1şını kırınım modeli benzer bir yapıya ve bir kalsiyum oksalat tepesine sahip olduğu tespit edildi. Literatür ile uyumludur. FT-IR spektrumunda, incelenen tüm sentezler için 3700 ile $2760 \mathrm{~cm}^{-1}$ arasındaki bölgede geniş bir spektrum gözlemlendi. $\mathrm{H}_{6}$ için $\mathrm{COM}$ yapısını ve $\mathrm{H}_{1}, \mathrm{H}_{2}, \mathrm{H}_{3}$ ve $\mathrm{H}_{4}$ için COD yapısını ortaya koyduğu görüldü. Diğer asitlerin sentetik kalsiyum oksalat üzerindeki etkileri SEM görüntüleri kullanılarak karşılaştırıldı. Partiküllerin boyutsal dağılımının düzgün ve sitrik asit ilave edilen $\mathrm{H}_{4}$ için diğerlerinden daha küçük olduğu durumlarda elde edildi. Glacial asetik asit eklenerek gerçekleşen sentezde partiküllerde kümelenme eğiliminin diğerlerine göre daha yüksek olduğu görüldü.

Anahtar Kelimeler: Böbrek Taşı, Kalsiyum Oksalat, Asit, XRD, FTIR.

\footnotetext{
*Corresponding Author: emineaytar@harran.edu.tr
} 


\section{Introduction}

Urinary stones are structures made up of urine crystals and colloid substances held together. The correct characterization of urinary stones is very important because it affects the choice and outcome of treatment. Stone formation in the urinary system is generally caused by the absence of crystallization inhibitors, the presence of crystallization enhancers, and some morphological factors. Crystallization inhibitors are critical to prevent stone formation in the urinary system (Figure 1) (Munoz and Valiente, 2005). Studies have shown that kidney stones begin to form when the urine is saturated with salts and small crystals appear (Sheehan, 1981). Although the reason for its occurrence is not fully understood, it has been stated that geographical factors, race, gender, and eating habits are effective in stone formation. Besides, one or more of nutrition, decrease in urine amount, obstruction of urine flow, metabolism disorders, drugs, traumas, chronic osseous and, urinary tract inflammation are factors in stone formation (Miller, 1996, Chewcharat and Gary Curhan, 2021). It has been suggested that prevent stone formation, including lemonade, fish oil (omega fatty acids), Phyllanthus niruri (P. niruri) and the Dietary Approaches to Stop Hypertension (DASH) diet (Garbens and Pearle, 2021).

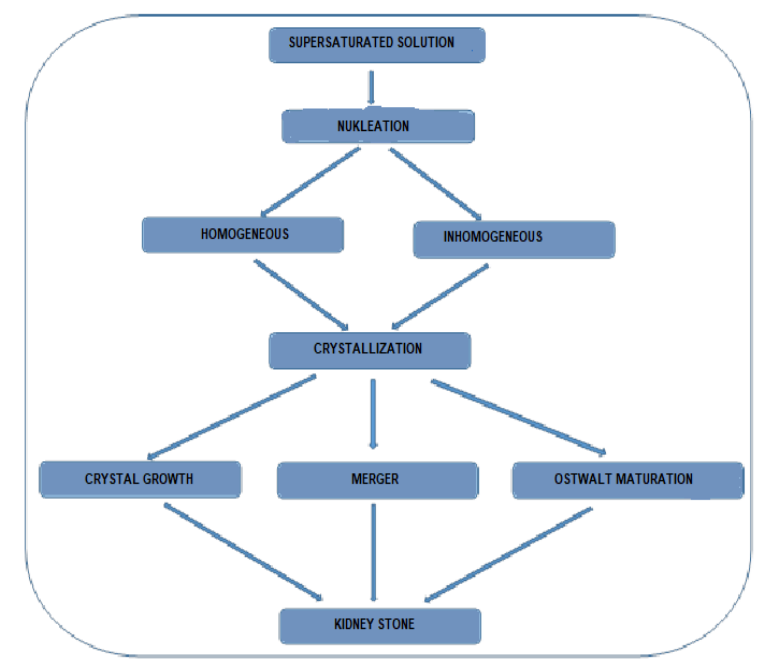

Figure 1. The formation process of kidney stone (Sheehan, 1981).

Kidney stones are composed of Calcium Oxalate, Uric Acid, Phosphate, and Rare Stones. Calcium Oxalate Stones constitute 60-70\% of kidney stones. Uric Acid Stones are seen in 5$6 \%$ of urinary system stones although they are excreted from the kidneys as the final product of metabolic activities. Phosphate Stones are seen as carbonate, apatite, struvite, brucite, and whitlockite form. 5\% of the stones are found as struvite and less than $2 \%$ as carbonate apatite. Cystine stones forming Rare Stones are seen in 1\% of stone patients (Çatar, 2010; Pınar, 2004; Yalçın et al., 2014).

Calcium oxalate, which contains $60-70 \%$ of kidney stones, is the main component of most people's kidney stones. Three hydrate forms of calcium oxalate are known with different chemical compositions and crystal structures: monohydrate $\left(\mathrm{CaC}_{2} \mathrm{O}_{4} \cdot \mathrm{H}_{2} \mathrm{O}, \mathrm{COM}\right)$, dihydrate $\left(\mathrm{CaC}_{2} \mathrm{O}_{4} \cdot 2 \mathrm{H}_{2} \mathrm{O}\right.$, COD) and, trihydrate $\left(\mathrm{CaC}_{2} \mathrm{O}_{4} \cdot 3 \mathrm{H}_{2} \mathrm{O}\right.$, COT $)$. COM crystals are mineralogically known as "Whewellite", COD crystals as "Weddellite" and COT crystals as "Caoxite" (Figure 2) (Akyol, 2006). 


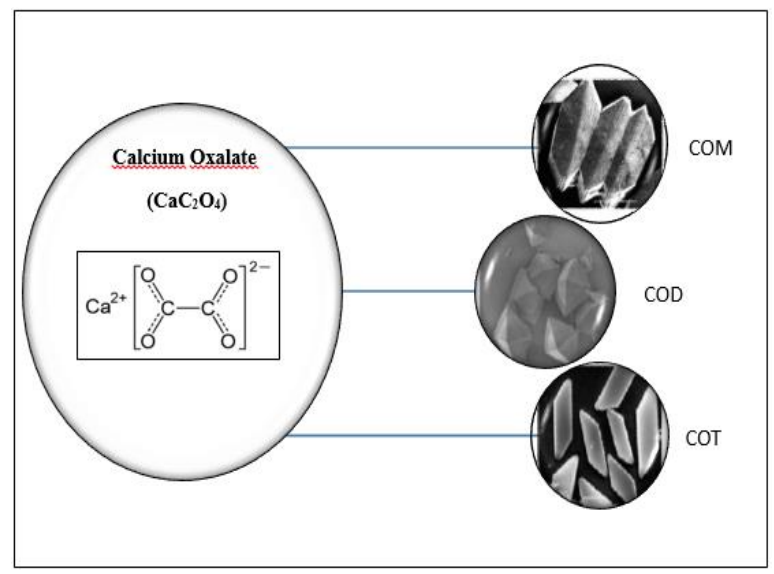

Figure 2. The SEM image of Calcium Oxalate Crystals (Akyol, 2006; Opalko et al., 1997).

The formation of kidney stones rarely occurs due to the strong effects of acid-rich proteins in the urine although calcium oxalate is highly saturated in human urine. Besides, proteins in urine play an important role in the transformation of COM into calcium oxalate dihydrate (COD), which does not turn into the urinary tract and kidney stones (Jung et al., 2004). The precipitation and growth of COM crystals or the conversion of COM nuclei into calcium oxalate dihydrate (COD) crystals, a less stable structure, prevent the development of kidney stones (Jung et al., 2005). Studies have shown that crystals in the structure of COD are easily excreted from the body with urine (Yu et al., 2004). The chemical analysis of the stone structure and which components will affect is very important in terms of determining the correct treatment method for this reason (Akyol and Öner, 2007; Ceylan et al, 2005; Öner and Calvert, 1994). Key crystallization parameters in determining the crystal structure and morphology of calcium oxalate are that temperature, additive, oversaturation, and stoichiometric conditions (Jung et al., 2004).

The surgical methods have been developed over time depending on the stone structure, stone burden, and stone localization to treat kidney stones. The chronological order of the methods developed to be used in the treatment of kidney stones is given in Table 1.

Table 1. The chronological order of the methods used in the treatment of kidney stones

\begin{tabular}{|c|c|}
\hline Method & Chronology \\
\hline URS & 1912, Hugh Hampton Young \\
\hline PNL & 1941, Rupel and Brown \\
\hline SWL & 1980, Christian Chaussy \\
\hline RIRS & 1983, Huffman et al. \\
\hline
\end{tabular}

Ureteroscopy (URS) is an endoscopic operation used to remove medium or large stones $(2 \mathrm{~cm})$ from the kidney and urethra. It is the process of breaking down stones by entering the urinary tract (urethra) and into the kidney with thin endoscopes (ureteroscopy) with cameras. It is seen with endoscopes and a camera from the canal where urine is made (urethra) and is reached to the urinary bladder (bladder). Then, the opening of the channel that brings urine from the kidney is seen in the urinary bladder and a guide wire is sent here to enter this channel. The stones inside are accessed with a flexible ureteroscope (flexible ureteroscope) and a rigid ureteroscope (semi-rigid ureteroscope). Stones in the urinary tract are crushed by laser or pneumatic stone 
crushing devices. Stones that remain in the urinary canal for a long time cause edema on the wall of the canal and stents are usually placed after the procedure to prevent obstruction of the urinary tract while stone fragments are poured from the urinary tract. The stent can be removed after the broken stones are removed and the edema in the urinary tract resolves. An x-ray or ultrasound may be done before stent removal to make sure the stones are completely gone. The stent is usually removed 1 week to 3 weeks after the URS operation. Stents that remain in the body for a long time can cause problems such as urinary tract infection, bleeding, and calcification, and after the URS operation, this infection can mix into the blood and cause serious conditions (http://drtepeler.com/uretero-renoskopik-tas-kirma-urs-nedir/).

Percutaneous nephrolithotomy (PNL) ( $\geq 2 \mathrm{~cm}$ ) is an endoscopic operation used to remove from the kidneys. There are different types such as Standard PNL, Mini Percutaneous Nephrolithotomy (Mini PNL), and Micro Percutaneous Nephrolithotomy (Micro PNL) depending on the patient's condition. A catheter is inserted into the urethra canal to view the kidney and the stones at the beginning of the process. Then, the patient is then turned to the prone position. The stone is localized with fluoroscopic imaging systems. A small incision of less than $1 \mathrm{~cm}$ is made on the back of the patient and the calyx, where the stone will be reached, is entered with a thin needle. After making sure that it is in the correct location, a guide wire is passed through the needle, and needles of increasing thickness are passed over this guide wire and the channel formed between the skin and the kidney is expanded. After the canal reaches a sufficient width, the nephroscope is advanced into the kidney through the canal by the surgeon. Ultrasonic or laser energies are used to break the stone. After the stone is divided into pieces, it is taken out of the kidney using tools called graspers or special baskets. Since there are no channels and instruments that will allow the stones to come out of the kidney, it is a disadvantage for the method that the stones are completely broken and left into the kidney and millimetric stones are dropped by the patient (Kölükçü et al., 2019).

Shock Wave Lithotripsy or SWL is the fragmentation of the stone by sending the high energy shock waves created outside the body to the stone inside the body through a reflector system. Shock waves are large amplitude sound waves, or in other words, high-intensity sound waves (Bal, 2013). SWL procedure has a positive result for small and medium stones $(1-2 \mathrm{~cm}$ and $<1$ $\mathrm{cm}$ ) lower urethral stones and suitable for more than $90 \%$ of patients. However, the success of the method depends on factors such as stone qualities and body structure. If the stone size is large, the SWL procedure requires several sessions but skin rash and kidney damage can be caused after repeated sessions. SWL procedure has a disadvantage in cases such as pregnancy, high risk of bleeding, uncontrolled infection, uncontrolled high blood pressure, very hard stone (cystine and calcium oxalate), the size and location of the stone, and the physical structure that makes it difficult to reach the stone (Müslümanoğlu et al., 2007).

Another method called Retrograde IntraRenal Surgery (RIRS) is a very new surgical method that can be applied in the treatment of kidney and urethral stones and is suitable for kidney stones up to $2 \mathrm{~cm}$ and stones occurring with special conditions. Flexible URS can be easily used on stones up to $20-25 \mathrm{~mm}$ in size with the technological developments in recent years. The most important advantage of this method is that the patient's hospital stay is short and the recovery process is very fast (Adayener et al. 2002). The use of the holmium laser in the RIRS method has been the biggest improvement.

Table 2 shows that the Treatment Methods Used in Different Parameters. It can be seen that the success rate at $<2 \mathrm{~cm}$ in the RIRS treatment method is \%90 in a retrospective study by Reşorlu et al. from this table. RIRS has preferred in cases of linkage disease, chronic lung disease, and severe obesity. The stone-free rate in the PNL group is \%92.8; while, it has been found as \%90 
in the RIRS group (Binbay et al., 2011; Reşorlu and Ünsal, 2011; Haciyev, 2015). In the study of Özçift et al., it has been found as \%59.6 in complex kidney stones while the stone-free rate for simple kidney stones in the 3rd month after the PNL operation has \%82.4. The success rate for complex stones has $\% 75.2$, and the success rate for simple stones has $\% 92.3$. While success has been achieved in \%94.2 of those with a stone size below $4 \mathrm{~cm}$ and $\% 84.3$ of those with a size between 4 and $10 \mathrm{~cm}$, this rate has been found to be $\% 67.4$ in stones larger than $10 \mathrm{~cm}$ (Özçift et al. 2013).

Table 2. The Treatment Methods Used with Different Parameters

\begin{tabular}{|c|c|c|c|c|c|c|c|}
\hline \multirow{3}{*}{$\begin{array}{l}\text { Treatm } \\
\text { ent } \\
\text { Metho } \\
\text { d }\end{array}$} & \multirow{3}{*}{$\begin{array}{c}\text { Operat } \\
\text { ion } \\
\text { Time } \\
\text { (m) }\end{array}$} & \multirow{3}{*}{$\begin{array}{l}\text { Time of } \\
\text { stay in } \\
\text { the } \\
\text { hospital } \\
\text { (Day) }\end{array}$} & \multirow[t]{3}{*}{$\begin{array}{c}\text { Anesthe } \\
\text { sia }\end{array}$} & \multirow{3}{*}{$\begin{array}{c}\text { Stone } \\
\text { dimensi } \\
\text { on }\end{array}$} & \multirow[t]{3}{*}{ Stone Type } & \multirow{2}{*}{\multicolumn{2}{|c|}{$\begin{array}{c}\begin{array}{c}\text { Success Rate } \\
\%\end{array} \\
\text { Age Range } \\
\end{array}$}} \\
\hline & & & & & & & \\
\hline & & & & & & Child & Adult \\
\hline \multirow[t]{2}{*}{ SWL } & \multirow[t]{2}{*}{$30-45$} & \multirow[t]{2}{*}{-} & \multirow[t]{2}{*}{-} & $\begin{array}{l}10-20 \\
\mathrm{Mm}\end{array}$ & $\begin{array}{l}\text { Uric Acid, } \\
\text { Xanthine,, } \\
\text { Triamterene, } \\
\text { İndiravir }\end{array}$ & 95 & 95 \\
\hline & & & & $20 \mathrm{~mm} \leq$ & $\begin{array}{c}\text { Cystine, calcium } \\
\text { oxalate } \\
\text { monohydrate, } \\
\text { Calcium } \\
\text { Phosphate, Struvite }\end{array}$ & 50 & 50 \\
\hline \multirow[t]{2}{*}{ RIRS } & \multirow[t]{2}{*}{$25-45$} & \multirow[t]{2}{*}{$1-2$} & \multirow[t]{2}{*}{ Local } & $\begin{array}{l}2 \mathrm{~cm} \geq \\
2-3 \mathrm{~cm}\end{array}$ & $\begin{array}{c}\text { (Non-opaque): Uric } \\
\text { Acid, Xanthine, } \\
\text { Triamteren, } \\
\text { Indiravir } \\
\end{array}$ & 91.5 & 90 \\
\hline & & & & $3 \mathrm{~cm} \leq$ & $\begin{array}{c}\text { (opaque): Calcium } \\
\text { Oxalate } \\
\text { Monohydrate, } \\
\text { Calcium } \\
\text { Phosphate, cystine, } \\
\text { Struvite }\end{array}$ & 58.8 & 50 \\
\hline \multirow[t]{2}{*}{ URS } & \multirow[t]{2}{*}{$20-60$} & \multirow[t]{2}{*}{$1-2$} & \multirow[t]{2}{*}{$\begin{array}{c}\text { General } \\
\text { Local }\end{array}$} & $\begin{array}{l}1 \mathrm{~cm} \geq \\
1-2 \mathrm{~cm}\end{array}$ & $\begin{array}{c}\text { Uric Acid, } \\
\text { Xanthine, } \\
\text { Triamterene, } \\
\text { İndiravir }\end{array}$ & 95.5 & 95.5 \\
\hline & & & & $2 \mathrm{~cm} \leq$ & $\begin{array}{c}\text { Calcium Oxalate, } \\
\text { Calcium } \\
\text { Phosphate, cystine, } \\
\text { Struvite }\end{array}$ & 91.5 & 91,5 \\
\hline & & & & $4 \mathrm{~cm} \geq$ & $\begin{array}{c}\text { Uric Acid, } \\
\text { Xanthine, } \\
\text { Triamterene, } \\
\text { İndiravir }\end{array}$ & 97 & 94.2 \\
\hline
\end{tabular}




\begin{tabular}{|c|c|c|c|c|c|c|c|}
\hline PNL & $25-90$ & $2-3$ & $\begin{array}{c}\text { General } \\
\text { Epidural }\end{array}$ & $4-10 \mathrm{~cm}$ & $\begin{array}{c}\text { Uric Acid, } \\
\text { Xanthine, } \\
\text { Triamterene, } \\
\text { İndiravir, } \\
\text { Cystine,Struvite, } \\
\text { Calcium Oxalate } \\
\text { Monohydrate, } \\
\text { Calcium Phosphate }\end{array}$ & 83 & 83 \\
& & $10 \mathrm{~cm} \leq$ & $\begin{array}{c}\text { Cystine, Struvite, } \\
\text { Calcium Oxalate } \\
\text { monohydrate, } \\
\text { Calcium Phosphate }\end{array}$ & 74 & 74 \\
\hline
\end{tabular}

Table 3 shows the general success rates in the treatment methods used in kidney and urethral stones $>2 \mathrm{~cm}$ and $\leq 2 \mathrm{~cm}$ in the literature. In many studies, RIRS and URS methods have been used together, according to the patient's condition (Aslan, 2010). The SWL method has been accompanied by the PNL method (Özçift et al. 2013; Kaba et al., 2005)

Table 3. The success rate of the used methods (\%)

\begin{tabular}{|c|c|c|}
\hline $\begin{array}{c}\text { RADIO-OPAQUE } \\
\text { STONES }\end{array}$ & $\mathbf{s} \mathbf{~ c m}$ & $>\mathbf{2} \mathbf{~ c m}$ \\
\hline PNL & 97 (Binbay et al., 2011) & 83 (Özçift et al. 2013) \\
\hline RIRS & 90 (Reşorlu and Ünsal, 2011) & 50 (Binbay et al., 2011) \\
\hline URS & $\begin{array}{c}95 \text { (Akyol and Öner, 2007; } \\
\text { Ceylan et al, 2005) }\end{array}$ & 91.5 (Aslan, 2010). \\
\hline SWL & $\begin{array}{c}\text { 95 (Sancak et al., 2015) } \\
\text { PNL+SWL }\end{array}$ & 50 (davarct et al., 2012) \\
\hline
\end{tabular}

The working areas and success rates can vary in the treatment methods used in kidney and urethral stone localization situations. All stone types can be crushed using a holmium laser. RIRS treatment success rates have been reported as $83 \%$ and $90 \%$ in the lower and upper calyces, respectively (Table 4) (Reşorlu and Ünsal, 2011). 
Table 4. The Success Rate in Stone Crushing Treatment Methods According to Stone Localization Status (\%)

\begin{tabular}{|c|c|c|c|c|}
\hline $\begin{array}{c}\text { Stone Settlement } \\
\text { Kidney/Urether }\end{array}$ & $\begin{array}{c}\text { SWL } \\
\text { Success \% }\end{array}$ & $\begin{array}{c}\text { RIRS } \\
\text { Success } \\
\%\end{array}$ & $\begin{array}{c}\text { URS } \\
\text { Success } \\
\%\end{array}$ & $\begin{array}{c}\text { PNL } \\
\text { Success \% }\end{array}$ \\
\hline Upper Calyx & 100 & 90 & - & 66.7 \\
\hline Middle Calyx & 68.0 & - & - & 100.0 \\
\hline Lower Calyx & 52.4 & 83 & - & 78.0 \\
\hline Pelvis & 76.5 & - & - & 86.7 \\
\hline Upper Ureter & 75 & - & 55.5 & - \\
\hline Middle Ureter & 76.9 & - & 52.8 & - \\
\hline Lower Ureter & 71.4 & - & 97.6 & - \\
\hline
\end{tabular}

The effects of additives on calcium oxalate crystallization, the addition of natural plant species extracts, the effect of various natural waters, the addition of acidic substances, the $\mathrm{pH}$ effect and, the contribution of some chemical compounds have been investigated in some studies. It has been found that Viburnum opulus's water has a reducing effect on $\mathrm{CaC}_{2} \mathrm{O}_{4}$ crystals to contribute to the treatment of kidney stone disease (Ongun, 2011); Block copolymers containing acrylic acid reduce the rate of calcium oxalate crystallization, reduce the crystal size, can be used as a barrier because they cause COD formation under appropriate experimental conditions (Akyol, 2006); It has been reported that the dandelion plant, which is used to reduce the effect of additives on calcium oxalate crystals and to transform into COD, can be useful in the treatment of kidney stone disease (Akyol et al., 2016; Akyol, 2016). The positive results have been obtained on the prevention of stone formation and partially effective treatment methods that can eliminate the vast majority have been found with the studies conducted. However, Daudon et al. expressed that urinary acidification by means of ammonium chloride or phosphoric acid may provoke the formation of uric acid calculi when urine $\mathrm{pH}$ is consistently maintained below 5.2. This problem continues to affect many people, and so, still many studies need to prevent kidney stones.

\section{Material and Methods}

In the study, for the synthesis of $\mathrm{CaC}_{2} \mathrm{O}_{4} ; 1.121 \mathrm{~g}$ of $\mathrm{NaC}_{2} \mathrm{O}_{4}$ has been dissolved in $0.65 \mathrm{ml}$ of distilled water in a beaker and $1 \mathrm{~g}$ of $\mathrm{CaCl}_{2}$ has been dissolved in $0.65 \mathrm{ml}$ of distilled water in the second beaker. The solutions prepared in two separate beakers have been added at the same time to $400 \mathrm{ml}$ of distilled water at $70{ }^{\circ} \mathrm{C}$ and this mixture has been evaporated to obtain a precipitate. The resulting precipitate has been left standing for a few minutes, then filtered and left to refrigerate for 5 minutes. In another study; Saturated solutions of $0.5 \mathrm{~g} \mathrm{CaCl}_{2}$ in $30 \mathrm{ml}$ of water in the 1 st beaker and $0.65 \mathrm{~g}$ of $\mathrm{NaC}_{2} \mathrm{O}_{4}$ in $30 \mathrm{ml}$ of water in the 2 nd beaker have been prepared separately and the saturated solutions prepared in $60 \mathrm{ml}$ of water at $70{ }^{\circ} \mathrm{C}$ in the $3 \mathrm{rd}$ 
beaker have been added at the same time, and the saturated solutions have been seen. The mixture has been drained without standing then left to cool for 5 minutes. In the third study, the solutions prepared with $1.21 \mathrm{~g} \mathrm{NaC}_{2} \mathrm{O}_{4}$ and $1 \mathrm{~g} \mathrm{CaCl}_{2}$ have been added to $80 \mathrm{ml}$ of water at 70 ${ }^{\circ} \mathrm{C}$ at the same time and the mixture has been kept at a constant temperature for 2.5 hours and then it has been allowed to cool for 5 minutes. After cooling, the mixture has been filtered. It was investigated how the effect of the amount of substrate and solvent on the structure of stone obtained by these three reactions. In all three studies, the same result has been found by obtaining $\mathrm{CaC}_{2} \mathrm{O}_{4}$ stones. Solutions have been prepared as $\mathrm{CaCl}_{2} 1 \mathrm{gr} 40 \mathrm{ml}$ distilled water and $\mathrm{NaC}_{2} \mathrm{O}_{4} 1,2 \mathrm{gr} 40 \mathrm{ml}$ distilled water and $80 \mathrm{ml}$ distilled water (heated to $70{ }^{\circ} \mathrm{C}$ ) has been kept for 2 hours. While $\mathrm{CaC}_{2} \mathrm{O}_{4}$ stone was formed by adding the obtained solutions at the same time, $1 \mathrm{ml}$ of lemon was added to the reaction. Similarly, the reaction was carried out in $\mathrm{CH}_{3} \mathrm{COOH}$ (1M), $\mathrm{CH}_{3} \mathrm{COOH}$ glacial acetic acid $(1 \mathrm{M}), \mathrm{C}_{6} \mathrm{H}_{8} \mathrm{O}_{7}(1 \mathrm{M})$ and $\mathrm{HCl}(1 \mathrm{M})$, respectively. The resulting mixture has been filtered and the crystals obtained have been washed with water and ethanol. It has been dried at $60{ }^{\circ} \mathrm{C}$ under a vacuum for 24 hours. Then, the stone structure has been determined by XRD, FT-IR and SEM methods. Synthesized samples and codes are given in Table 5. XRD studies have been performed to obtain the information of phases and crystalline quality. The measurements have been done on a Rigaku Dmax 2000 Diffractometer at $40 \mathrm{kV}$ and $30 \mathrm{~mA}$ using $\mathrm{CuK}$ alpha radiation. The range of $2 \theta$ scanning speed $(0.02)$ has been performed from $20^{\circ}$ to $70^{\circ}$. Jade has been used to determine of crystalline phase. FT-IR spectra have been recorded with Perkin-Elmer Two UATR-FT-IR spectrophotometers and have been measured in the range of $4000-400 \mathrm{~cm}^{-1}$ by using the ATR accessory with a diamond ATR crystal. A Zeiss (EVO 50) scanning electron microscope (SEM) has been used to determine of the morphology of synthesize Calcium oxalate (Önal, 2020)

Table 1. Synthesized Samples and Codes

\begin{tabular}{|c|c|}
\hline Samples & Acids used during this synthesize \\
\hline $\mathbf{H}_{\mathbf{1}}$ & $\mathrm{CH}_{3} \mathrm{COOH}$ (Acetic Acid) and $\mathrm{CaC}_{2} \mathrm{O}_{4}$ \\
\hline $\mathbf{H}_{2}$ & $\mathrm{CH}_{3} \mathrm{COOH}$ glacial (Acetic Acid glacial) and $\mathrm{CaC}_{2} \mathrm{O}_{4}$ \\
\hline $\mathbf{H}_{3}$ & $\mathrm{HCl}$ (Hydrochloric Acid) and $\mathrm{CaC}_{2} \mathrm{O}_{4}$ \\
\hline $\mathbf{H}_{4}$ & $\mathrm{C}_{6} \mathrm{H}_{8} \mathrm{O}_{7}$ (Citric Acid) and $\mathrm{CaC}_{2} \mathrm{O}_{4}$ \\
\hline $\mathbf{H}_{5}$ & Lemon and $\mathrm{CaC}_{2} \mathrm{O}_{4}$ \\
\hline $\mathbf{H}_{6}$ & $\mathrm{CaC}_{2} \mathrm{O}_{4}($ Calcium Oxalate) \\
\hline
\end{tabular}

\section{Research Findings}

\subsection{XRD Analysis}

XRD spectra of all samples are given in Figure 3. The X-ray diffraction pattern for all syntheses studied has a similar structure and has a calcium oxalate peak numbered 01-075-1313 (Figure 3). It is compatible with the literature (Pınar, 2004; Yalçın et al., 2014; Önal, 2020). $\mathrm{H}_{2}$ and $\mathrm{H}_{4}$ have sharper spectrum peaks, while $\mathrm{H}_{3}$ has less severe spectrum peaks. This is expected due to the action of hydrochloric acid. 


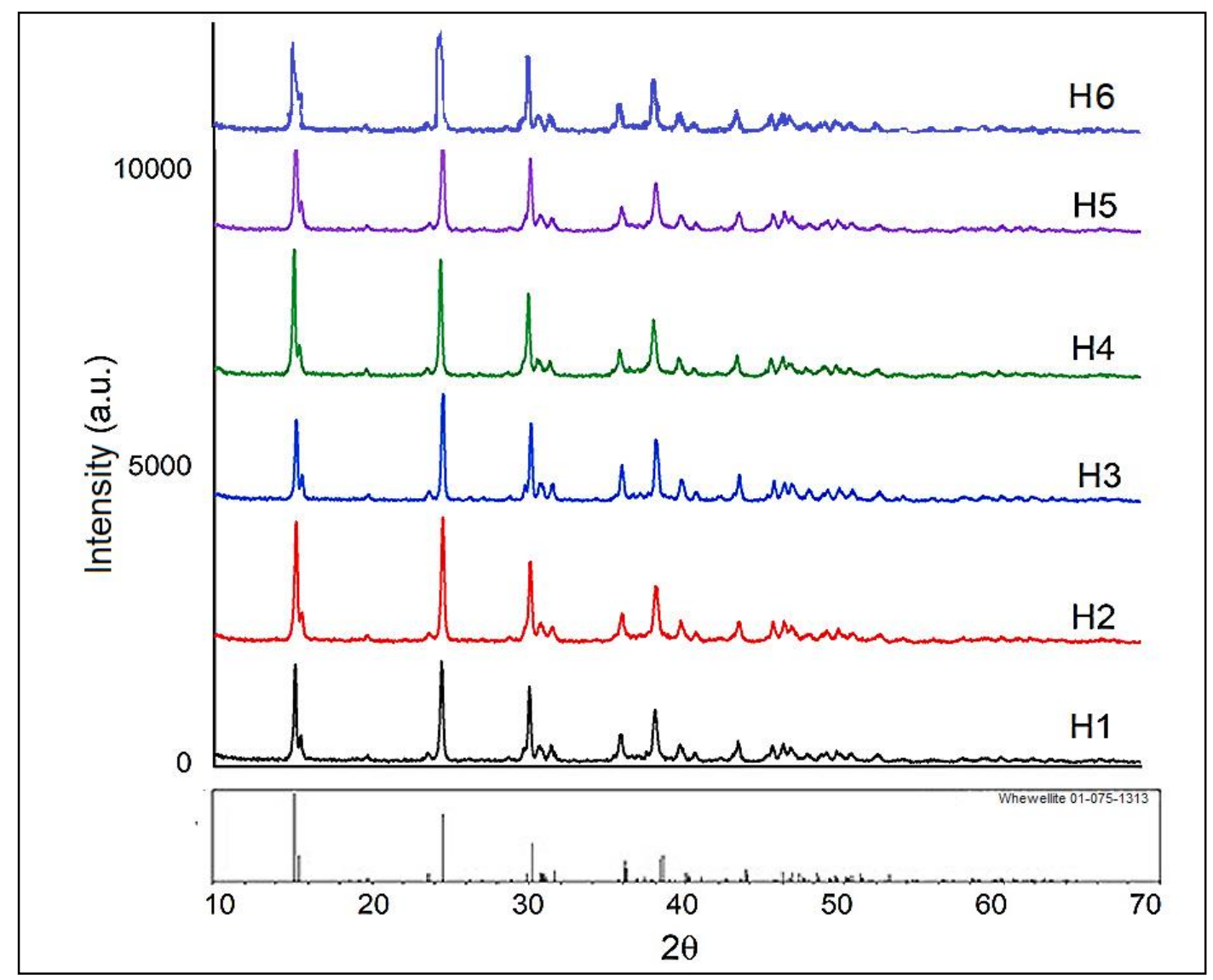

Figure 3. XRD Spectrum of Synthesized Substances

\subsection{FT-IR Analysis}

FTIR spectra of all samples are given in Figure 4. Peaks at 1600, 1378, 1313, 948, 863, and 772 $\mathrm{cm}^{-1}$ have been observed in the spectrum for all synthesized substances. The spectra have the calcium oxalate peak at 1603,1313 , and $779 \mathrm{~cm}^{-1}$ in all samples. A broad spectrum peak has been observed in the region between 3700 and $2760 \mathrm{~cm}^{-1}$ for all studied syntheses. This spectrum peak is more severe for $\mathrm{H}_{1}, \mathrm{H}_{2}, \mathrm{H}_{3}$, and $\mathrm{H}_{4}$, and has a neck peak around $3065 \mathrm{~cm}^{-1}$. It is flatter for $\mathrm{H}_{6}$. It is seen that it transforms into a COD structure while $\mathrm{H}_{6}$ reveals the COM structure for $\mathrm{H}_{1}, \mathrm{H}_{2}, \mathrm{H}_{3}$, and $\mathrm{H}_{4}$. 


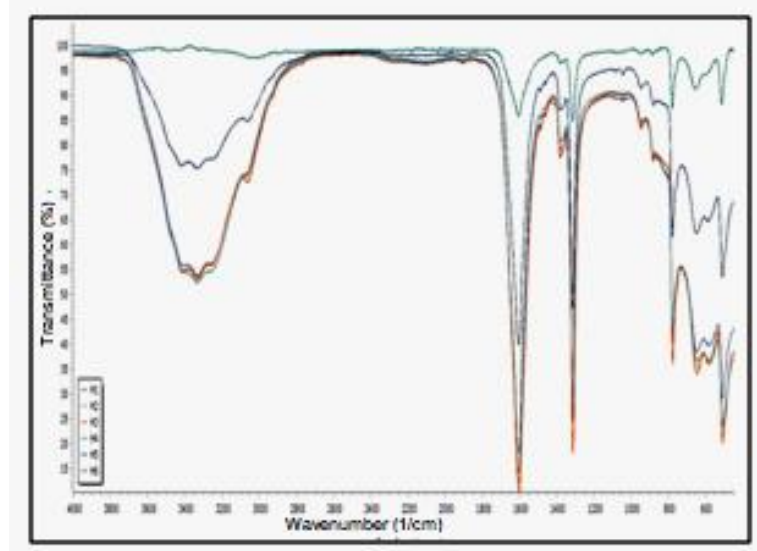

Figure 4. FTIR Spectrum of Synthesized Substances

\subsection{SEM Analysis}

To investigate the effect of some acids on synthetic calcium oxalate, microscopically obtained images have been obtained by using SEM. The dimensional distributions of the particles have been uniform and smaller than the others for the $\mathrm{H}_{4}$ which citric acid have been added. The tendency to cluster in the particles has been higher than the others in the synthesis obtained by adding glacial acetic acid. The situation thought to be caused by $\mathrm{HCl}$ acid in XRD has not been seen in SEM. Although the clustering is high, the presence of finer particles is related to this situation (Figure 5).
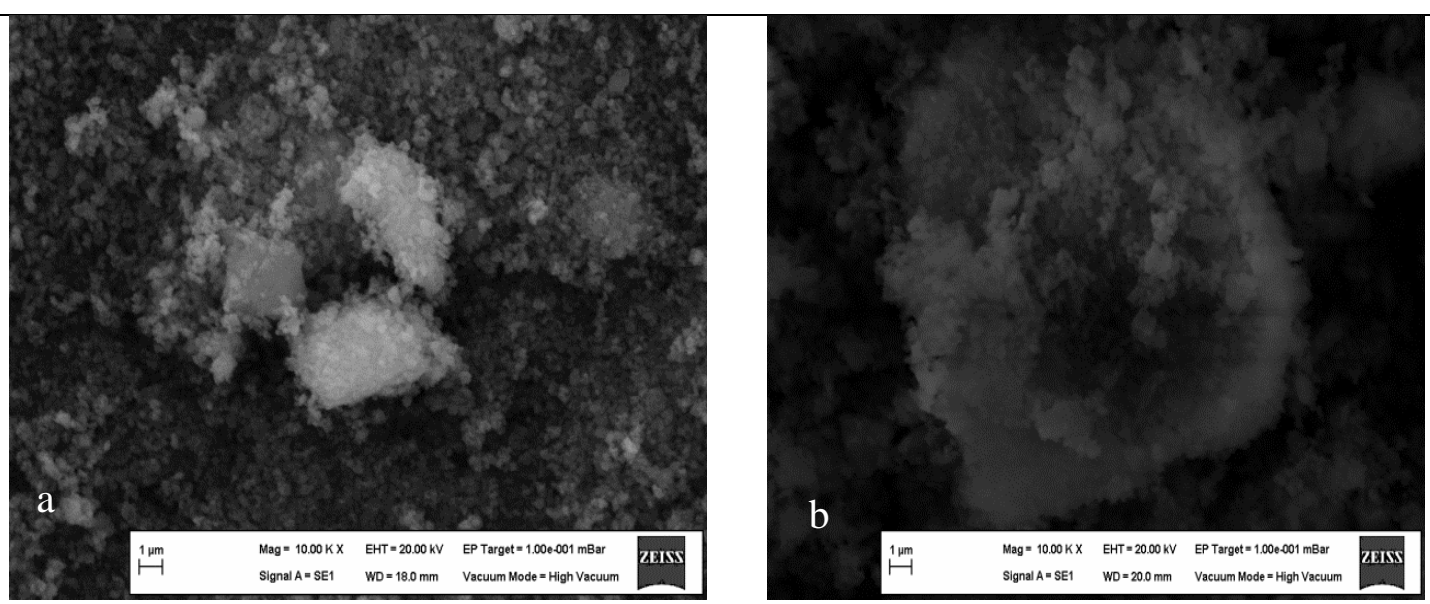


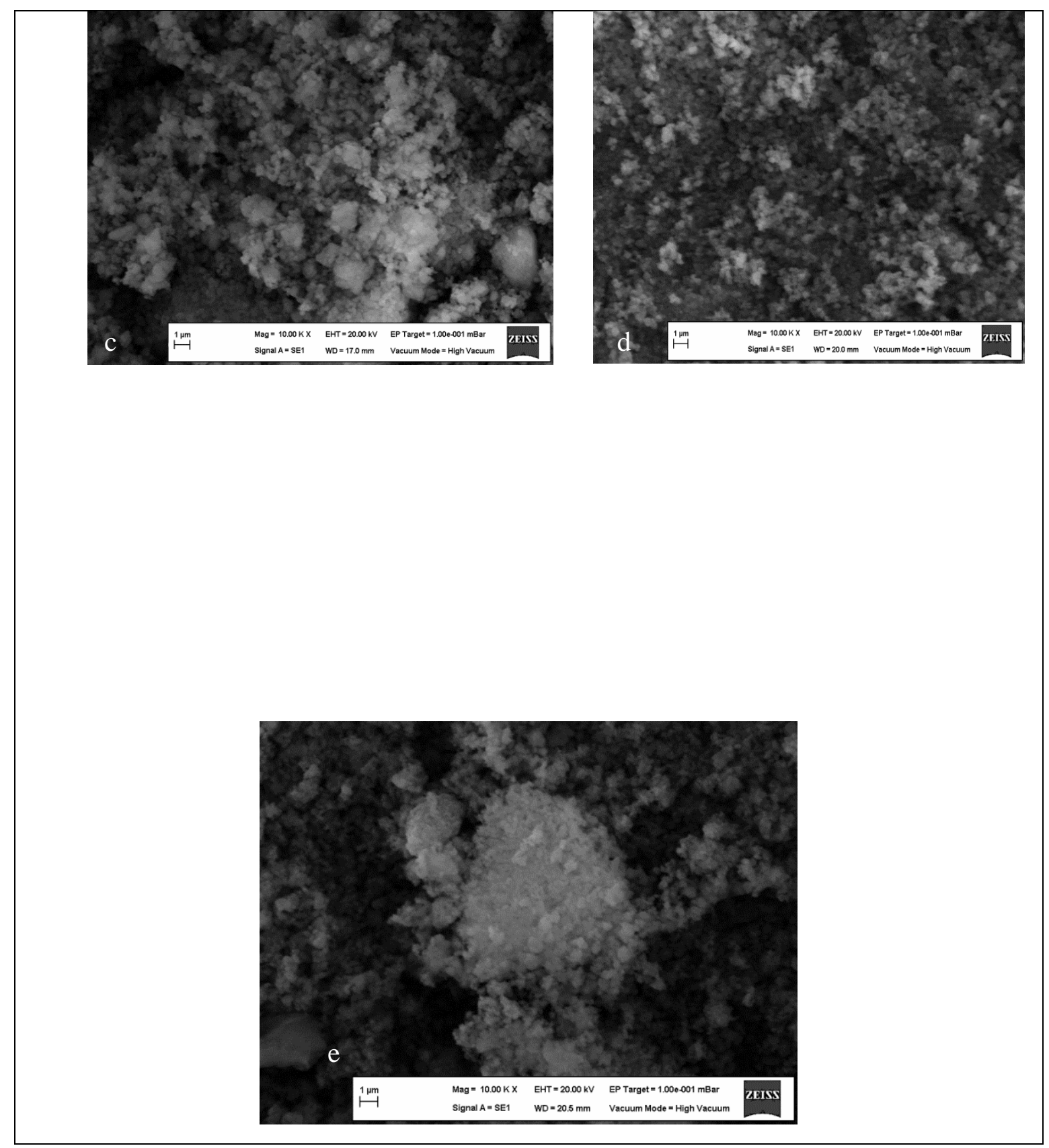

Figure 5. SEM Image of Synthesized Samples a: $\mathrm{H}_{1}$, b: $\mathrm{H}_{2}$, c: $\mathrm{H}_{3}$, d: $\mathrm{H}_{4}$, e: $\mathrm{H}_{5}$

\section{Results}

Kidney stones are still an important and common disease today. Despite the advancing technology, the high reproducibility of kidney stones and the high-risk factors of medical and surgical treatments have led to new searches. It is expected that new technologies to be developed will increase the success of the treatment, reduce the side effects, and shorten the treatment period. At this point, the determination of the composition and crystal structure of the stone is very important in terms of determining the correct treatment method. SWL has an advantageous treatment method due to lack of complications, short treatment process, not requiring anesthesia, and applicability to kidney stones smaller than $2 \mathrm{~cm}$, however, it is not preferred due to failure in stones larger than $2 \mathrm{~cm}$, difficulty in hard stones and increase in pregnancy complication rate. The advantage of the PNL treatment method is that it can be 
applied to all stone types with a high stone burden and hard stone. The mini PNL has a disadvantage since there are no channels and instruments that will allow the stones to exit from the kidney, broken stones lefts in the kidney and millimetric stones should be dropped by the patient. Mini PNL is a method designed for pediatric stone patients. It has been reported that Mini PNL has almost the same success rates as standard PNL for stones between 1- and $2.5 \mathrm{~cm}$. However, it is not preferred in patients with kidney stones $>4 \mathrm{~cm}$, due to the increase in complication rate if the procedure time is prolonged. It is reported that Mini PNL provides an advantage with a shorter recovery time compared to standard PNL. The fact that PNL is not a preferred surgical method in pregnant women is a disadvantage for the PNL treatment method due to the position shape, the length of the operation time, and the need to use fluoroscopic imaging. Therefore, the treatment of pregnant patients with a large stone burden requiring the PNL treatment method should be kept until after delivery. URS (Ureteroscopy) urethral stone treatment method, which has fewer complications than PNL and has a shorter hospital stay, is the treatment method that is easily preferred instead of the PNL treatment method in hard stones larger than $2 \mathrm{~cm}$ and $2 \mathrm{~cm}$. The disadvantages of the URS method are its operation with a rodlens system, its dimensions not being suitable for use, and its inability to enter into routine use due to insufficient tools for crushing and removing stones. However, with the advancing technology, rigid and flexible ureteroscope with small diameters, wide field of vision, and high image quality have been produced. The ability to access the upper urinary system thanks to a flexible ureteroscope with high movement (deflection) ability and relatively more durable has provided an advantage to the URS method. The most important advantage of the URS method is that the fragmentation and stone removal rates up to \%100 and the operation time is short since additional procedures such as stone removal are not dealt with. The disadvantages of the URS method are that the URS method cannot break very hard stones, it can cause tissue damage due to weak energy control, the perforation rate close to $40 \%$, and the probe restricts the URS movements in lower calyceal stones. It is an advantage for the RIRS treatment method that the RIRS method, which is another treatment method, can be easily applied to patients who are obese, have chronic diseases, and have a stone size of $<2 \mathrm{~cm}$. The introduction of the holmium laser to the RIRS method has increased the use of the RIRS treatment method. In this way, it is another advantage that it can break all kidney stones of different structures and sizes. Compared to PNL, less radiation exposure, less hospital stay and lower complication rates are the most important advantages of RIRS. The cost of the holmium laser used in the RIRS method is one of the most important disadvantages of RIRS. Besides, using URS and RIRS treatment methods is an important advantage to achieve maximum success in cases of large stone burden with endoscopic urethral stone-breaking treatment. The anatomy of the kidney, the size of the stone, its location and structure, anatomical factors of the patient, surgical technique and experience are among the factors that affect success. Generally, these methods have some disadvantages besides their advantages, and there is a need to develop new treatment methods for the treatment of kidney stones. The $\mathrm{CaC}_{2} \mathrm{O}_{4}$ stone has been synthesized and examined using XRD, FTIR, and SEM in this study. The X-ray diffraction pattern of all syntheses has a similar structure and has a calcium oxalate peak. In the FT-IR spectrum, a broad-spectrum peak has been observed in the region between 3700 and $2760 \mathrm{~cm}^{-1}$ for all studied syntheses. $\mathrm{H}_{6}$ is flatter, while, this spectrum peak is more severe for $\mathrm{H}_{1}, \mathrm{H}_{2}, \mathrm{H}_{3}$, and $\mathrm{H}_{4}$ and has a neck peak around $3065 \mathrm{~cm}^{-1}$. It reveals the COM structure for $\mathrm{H}_{6}$, and the COD structure for $\mathrm{H}_{1}, \mathrm{H}_{2}, \mathrm{H}_{3}$, and $\mathrm{H}_{4}$. For all synthesized substances, peaks have been observed at 1600, 1378, 1313, 948, 863, and $772 \mathrm{~cm}^{-1}$ in the spectrum. Besides, it is thought that the peak at $1047 \mathrm{~cm}^{-1}$ in the spectrum belongs to the XRD pattern with 01-075-1313 pdf number, and it has been only seen in $\mathrm{H}_{3}$ and $\mathrm{H}_{5}$. The effects of other acids on synthetic calcium oxalate have been compared by using SEM images. It has been obtained where the dimensional distribution of the particles has uniform and smaller than the 
others for the $\mathrm{H}_{4}$ which citric acid has been added. It has been observed that the tendency to cluster in the particles was higher than the others in the synthesis by adding glacial acetic acid.

Acknowledgment: There is no conflict of interest among the authors. This work-has been supported by the Research Fund of Harran University (HUBAK Projects No: 19304, Sanliurfa, Turkey). We also thank Application and Research Center for Science and Technology (HÜBTAM).

\section{References}

Munoz, J.A., Valiente M. 2005. Effects of trace metals on the inhibition of calcium oxalate crystallization. Urological Research, 33(2005), 267-272.

Sheehan, M.E. 1981. The Kinetics of Crystal Growth of Calcium Oxalate, Ph. D. Thesis, State University of New York at Buffalo.

Miller, J.D. 1996. Crystallization kinetics of calcium oxalate in simulated urine. The University of Arizona. Ph.D. Thesis, 246p.

Çatar, Ö. Ü. 2010. Investigation of gene polymorphisms affecting kidney stone formation. Master Thesis, Haliç University Institute of Science and Technology, Molecular Biology and Genetics Program, 1-10.

Pinar, Ş., 2004. Crystal Structure Research and Qualitative Analysis of Kidney Stones by XRay Powder Diffraction Method Erciyes University, Master Thesis.

Yalçın, S., Dilsiz, N., Gülüm, M. 2014. Investigation of the composition of kidney stone taken from Sanliurfa, south of Turkey, Urolithiasis 42(4)(2014), 363-364.

Akyol, E. 2006. Effect of Block Copolymers on Calcium Oxalate Crystallization, PhD Thesis, YTU Institute of Science and Technology, Istanbul.

Opalko, F.J., Adair, J.H., Khan, S.R. 1997. Heterogeneous nucleation of calcium-oxalate trihydrate in artificial urine by constant composition. Journal of Crystal Growth, 181(1997), 410-417.

Jung, T., Kim, W.S. and Choi, C.K. 2004. "Biomineralization of Calcium Oxalate for Controlling Crystal Structure and Morphology", Materials Science and Engineering, C, 24(2004), 31-33.

Jung, T., Kim, W.S. and Choi, C.K. 2005."Crystal Structure and Morphology Control of Calcium Oxalate Using Biopolymeric Additives in Crystallization", Journal of Crystal Growth, 279(2005), 154-162.

Yu, J., Tang, H., Cheng, B. 2005. Influence of PSSS additive and temperature on morphology and phase structures of calcium oxalate. Journal of Colloid and Interface Science, 288(2005) 407-411.

(a) Akyol, E. and Öner, M. 2007. "Inhabition of Calsium Oxalate Monohydrate Crystal Growth Using Polyelectrolytes", Journal of Crystal Growth, 307(2007), 137-144. (b) Ceylan, K., Sünbül, O., Shin, A., Güneş, M. 2005. Ureteroscopic Treatment of Ureteral Lithiasis with 
Pneumatic lithotripsy: Analysis of 287 Procedures in a Public Hospital. Urol Res, 33(2005), $422-5$.

Öner, M. and Calvert. P. 1994. "Effect of Architecture of Acylic Polyelectrolytes on Inhibition of Oxalate Crystallization”, Materials Science \& Engineering, 2(1994), 93-101.

http://drtepeler.com/uretero-renoskopik-tas-kirma-urs-nedir/

Kölükçü, E., Kılıç, Ş., Parlaktaş, B. S., Uluocak, N., Atılgan, D., Alkan, E., Erdemir, F., Eser, M.A., 2019. Our Stone Breaking Results with Extracorporeal Shock Waves in the Treatment of Upper Ureter Stones. J Health Sci Med, 2(1)(2019), 13-17.

Bal, F. 2013. The Effectiveness of Percutaneous Nephrolithotomy and Retrograde Intrarenal Surgery in Small Kidney Stones $<2 \mathrm{~cm}$. Master thesis, Klrlkkale University Faculty of Medicine, Department of Urology, Kırıkkale.

Müslümanoğlu, A., Esen, T., and Tefekli, A. 2007. Urinary System Stone Disease, Istanbul: Nobel Medical Bookstores.

Adayener, C., İşeri, C., Şenkul, T., Kardemir, K., Baykal, K., Erden, D. 2002. Recurrent Stone Disease: An Epidemiological Study Turkish Journal of Urology 28(4)(2002).

Binbay, M., Erbin, A., Müslümanoğlu, A. Y., 2011. Role of percutaneous nephrolithotomy and retrograde intrarenal surgery in the treatment of lower renal calyceal stones. Haseki Training and Research Hospital, Urology Clinic, İstanbul, 2(2011), 331-333.

Chewcharat, A., Curhan, G. 2021. Trends in the prevalence of kidney stones in the United States from 2007 to 2016. Urolithiasis 49(2021), 27-39.

Reşorlu, B., Ünsal, A., 2011. 'Retrograde Intrarenal Surgery in the Treatment of Kidney Stones (RIRC)'. Ministry of Health, Keçiören Training and Research Hospital, Urology Clinic, Ankara Turk Urol Sem 2(2011), 64-7.

Haciyev, P. 2015. Comparison of retrograde intrarenal surgery and micro percutaneous techniques in the treatment of kidney stones smaller than $2 \mathrm{~cm}$. Ankara University Faculty of Medicine, Department of Urology, Specialty Thesis in Medicine, (2015), 2-9.

Özçift, B., Bal, K., Bölükbaşı, A. and Dinçel, Ç. 2013. Our Percutaneous Nephrolithotomy Experience in the Treatment of Kidney Stones: 200 Cases, 20(2)(2013), 62-63.

Aslan, Y., Kırılmaz, U., Tuncel, A., Nalçacıoğlu, V., Balcı, M., Atan, A., 2010. 'Our Results of Rigid Ureteroscopy and Pneumatic Lithotripsy in Patients with Ureteral Stones.' Ministry of Health Ankara Numune Training and Research Hospital, 3. Urology Clinic, Ankara. Turkish Journal of Urology 36(3)(2010), 263-269.

Kaba, M., Pirinçi, N., Taken, K., Kaba, S., Geçit, İ., Eren, H., Demir, M., Ceylan, K. 2005. Percutaneous Nephrolithotomy Experience in Pediatric Kidney Stones. Van Medical Journal 22(3)(2005), 173-176.

Ongun, K. 2011. Investigation of the Effects of Natural and Synthetic Additives on Calcium Oxalate Crystallization, Master's thesis, YTU Graduate School of Natural and Applied Sciences, Istanbul. 
Akyol, E., Ongun, K., Kirboga, S., Oner, M. 2016. A kinetic study for calcium oxalate crystallization in the presence of Viburnum opulus extract. Biointerface Research In Applied Chemistry, 6(2016), 1059-1063.

Akyol, E. 2016. " Investigation of the Effect of Dandelion (Taraxacum Offcinale) Plant on Calcium Oxalate Monohydrate Crystal Growth." I Ĭglv University Journal of the Institute of Science, 6.3(2016), 97-105.

Sancak, E. B., Burak, E., Reşorlu, B. 2015. Anatolian Journal of Clinical Investigation. Cilt. 9 Say1 3 (2015), s161-166.

Davarc1, M., Rifaioğlu, M., Yalçınkaya, F. R., İnci, M. 2012. Two-Year Shock Wave Stone Scratching Results for Urinary System Stones. Dicle Medical Journal/39 (3)(2012), 377-380.

Daudon, M., Frochot, V., Bazin, D., Jungers, P., 2018. Drug-Induced Kidney Stones and Crystalline Nephropathy: Pathophysiology, Prevention and Treatment. Drugs 78(2)(2018), 163-201. doi: 10.1007/s40265-017-0853-7. PMID: 29264783.

Garbens, A., and Pearle, M.S., 2021. Causes and Prevention of Kidney Stones: Separating Myth from Fact. BJUI (2021). https://doi.org/10.1111/bju.15532

Güvenç, A. A., Atioğlu, Z., \& Akkurt, M. 2019. Bazı Üriner Sistem Taşlarının X-Işını Toz Kırınım Yöntemi ile Nitel Analizi. Erciyes Üniversitesi Fen Bilimleri Enstitüsü Dergisi, 35(3)(2019), 59-77.

Önal, H. 2020. Böbrek Taşları ve Tedavi Yöntemleri, Harran Üniversitesi, Yüksek Lisans Tezi. 